\section{Keeping pace with cancer}

I $\mathrm{n}$ the interface between basic and clinical science, important steps are being made towards a more focused understanding and treatment of cancer. In this special Focus, Nature Medicine is proud to present a collection of Reviews and a Perspective tackling some of the most exciting issues in translational cancer research, discussing recent advances and providing a view of what to expect in the near future.

The advent of cancer genomics and targeted therapies has the potential to rapidly change the clinical landscape of cancer. Ongoing efforts to integrate the deluge of information generated by sequencing platforms are affording us a close look at the different stages of tumor evolution. The coming of age of targeted therapies is revealing the intricacies of tumor behavior and the crucial contribution of environmental factors to treatment responses, providing insights into how tumors respond to therapy and why therapies fail. In this focus, experts in translational cancer research provide in-depth analyses and insight into our recent progress unraveling the biology underlying tumor progression, as well as therapeutic responses and resistance

Therapy resistance is an important unmet clinical need, both in the form of intrinsic unresponsiveness and acquired resistance. It is also emerging as a challenge to the clinical application of conceptual paradigms such as synthetic lethality or oncogene addiction. In their Perspective, Christopher J. Lord and Alan Ashworth discuss strategies to overcome resistance to PARP inhibitors that induce synthetic lethality in BRCA-deficient tumors. Curtis R. Chong and Pasi A. Jänne analyze the mechanisms of intrinsic and acquired resistance to EGFR-targeted therapies and try to identify common patterns that could lead to prevention and treatment of tumor recurrences. Piro Lito, Neal Rosen and David B. Solit recount the clinical ups and downs of BRAF-targeted therapies and provide a model for how resistance evolves to bypass single-target therapies. Dereck Amayke, Zainab Jagani and Marion Dorsch focus on the role of Hedgehog activation in cancer and analyze present hurdles and future challenges to therapeutically targeting this pathway.

A complication of targeting oncogenic driver pathways such as Hedgehog is the contribution of signaling crosstalk between the tumor cells and their surroundings. The emerging relevance of the tissue environment in tumor progression is discussed in the review by Daniela F. Quail and Johanna A. Joyce. The authors explore the evolving concept of targeting the microenvironment to revert, or eliminate, its tumor-promoting properties, in hopes of forestalling both primary and metastatic tumors.

Clinically, metastatic disease remains a formidable challenge. The dearth of successful antimetastatic agents may stem from our lagging understanding of the multifaceted nature of how cancers spread. In this focus, we try to integrate recent advances in translational research in metastasis. Wai Leong Tam and Robert A. Weinberg analyze the epigenetic mechanisms that regulate the process of epithelial-to-mesenchymal transition and discuss how it contributes to our current perception of the process of cancer metastasis. And Liling Wan, Klaus Pantel and Yibin Kang provide an up-to-date perspective on the biology of metastasis and a critical view of potential strategies to target disseminating tumor cells, dormant disease and overt metastases.

The diverse topics included in this focus underscore the dynamic progress of current cancer research. New targets are actively sought beyond the constrictions of primary tumor oncogenes, and clinical insights are driving our growing understanding of tumor heterogeneity and evolution. Nature Medicine hopes that this collection provides inspiration for the community and propels translational cancer research further towards its goals

In closing, we thank Genentech for their financial support to produce this special Focus on cancer. Nature Medicine is solely responsible for the content of these pages. \section{medicine}

www.nature.com/naturemedicine

EDITORIAL OFFICE

medicine@us.nature.com

75 Varick Street, Fl 9, New York, NY 10013 1917

Tel: (212) 726 9325, Fax: (212) 6835751

Chief Editor: Juan Carlos López

Chief News Editor: Roxanne Khamsi

Senior News Editor: Elie Dolgin

Senior News Editor: Elie Dolgin
Senior Editors, Reviews and News and Views:

Senior Editors, Reviews and
Carolina Pola, Meera Swami

Senior Editors, Research Manuscripts:

Victoria Aranda, Michael Basson,

Eva Chmielnicki, Kevin Da Silva,

Alison Farrell, Randy Levinson

Editor, Technical Reports: Diane Gershon

Copy Editors: Katherine Gora, Heidi Reinholdt

Senior Production Editor: Matt Hansen

Senior Production Editor: Matt Hansen
Senior Illustrator/Cover Design: Katie Vicari

Senior Illustrator/Cover Desig
Illustrator: Marina Corral

Editorial Assistant: Siri Crane

MANAGEMENT OFFICES

NPG New York

75 Varick Street, Fl 9, New York, NY 10013

1917

Tel: (212) 726 9200, Fax: (212) 6969006

Publisher: Melanie Brazil

Executive Editor: Veronique Kiermer

Chief Operations Officer: John Carrol

Head of Nature Research \& Reviews

Marketing: Sara Girard

Marketing Manager: Samantha Savalio

Production Coordinator: Diane Rios

Head of Web Services: Anthony Barrera

Web Production Editor: Eddie Jones

NPG London

The Macmillan Building, 4 Crinan Street, London N1 9XW

,

Tel: 44207833 4000, Fax: 442078434996

Publishing Director: Alison Mitchell

Editor-in-Chief, Nature Publications: Philip

Campbell

NPG Nature Asia-Pacific

Chiyoda Building, 2-37 Ichigayatamachi, Shinjuku-ku, Tokyo 162-0843

Tel: 8133267 8751, Fax: 81332678746

Tel: 8133267 8751, Fax: 81332678746
Regional Managing Director — Asia-Pacific:

David Swinbanks

Operations Director: Hiroshi Minemura

Senior Marketing Manager: Sachiyo Ikeda

Asia-Pacific Sales Director: Kate Yoneyama

Asia-Pacific Sales Manager: Ken Mikami 